\title{
Glucose Phosphate Isomerase Deficiency with Congenital Nonspherocytic Hemolytic Anemia: A New Variant (Type Nordhorn). II. Purification and Biochemical Properties of the Defective Enzyme
}

\author{
H. Arnold, ${ }^{[14]}$ K. G. Blume, and G. W. Löhr \\ Department of Internal Medicine, University of Freiburg, Freiburg, Germany \\ W. Sahröter, H. H. Koch, and B. Wonneberger \\ Department of Pediatrics, University of Hamburg, Hamburg, Germany
}

\begin{abstract}
Extract
The genetic variant of glucose phosphate isomerase (GPI) with hereditary nonspherocytic hemolytic anemia (GPI-Nordhorn) is purified 20,000-fold in a one-step procedure with a yield of $25 \%$. A specific activity of about $100 \mathrm{IU}$ per mg protein is obtained. The isoelectric point of the variant enzyme is 9.80 , which is slightly higher than normal. The molecular weight is 94,000 . Kinetic studies with the isolated enzyme gave results which are comparable to normal: $\mathrm{K}_{m}$ (glucose 6-phosphate $(\mathrm{G}-6-\mathrm{P})$ ) = $660 \mu \mathrm{M}, \mathrm{K}_{\mathrm{m}}$ (fructose 6-phosphate $\left.(\mathrm{F}-6-\mathrm{P})\right)=97 \mu \mathrm{M}, \mathrm{K}_{\mathrm{i}}$ 6-phosphogluconate (6-PG) $(\mathrm{G}-6-\mathrm{P})=43 \mu \mathrm{M}, \mathrm{K}_{\mathrm{i}}$ 6-PG $(\mathrm{F}-6-\mathrm{P})=19 \mu \mathrm{M}, \mathrm{K}_{\mathrm{i}}$ 2,3-diphosphoglycerate (2,3$\mathrm{DPG})(\mathrm{F}-6-\mathrm{P})=850 \mu \mathrm{M}, \mathrm{pH}$ optimum $(\mathrm{G}-6-\mathrm{P})=8.0$, and $\mathrm{pH}$ optimum (F-6-P) $=8.5$. It can be assumed that a genetically determined amino acid substitution causes the alteration of isoelectric point, electrophoretic migration, and increased thermolability but does not affect the active site of the enzyme.
\end{abstract}

\section{Speculation}

By the preparation of an enzyme variant reported herein a possibility is presented to obtain further structural characteristics by means of fingerprinting and amino acid analysis. It might be possible to correlate functional peculiarities to the altered structural properties of variant enzymes.

\section{Introduction}

In 1967 Baughan et al. [4] published the first observation of GPI (D-glucose-6-phosphate-ketol-isomerase (EC. 5.3.1.9)) deficiency as a cause of hemolytic nonspherocytic anemia. As in the case of G-6-P dehy- drogenase, the results reported so far suggest a pronounced molecular heterogeneity of GPI deficiency. All variants with decreased enzyme activity differ with respect to electrophoretic migration and to behavior and extent of thermal inactivation. It can be assumed 
that these alterations of physicochemical properties are caused by single amino acid substitutions. Whether the kinetic properties of the variant enzymes are affected can only be decided by kinetic studies with highly purified enzyme preparations. Furthermore, the kinetic data represent variables for differentiation of genetic variants.

We report the purification of a new enzyme variant (GPI-Nordhorn) following a method described earlier $[2,3]$. The kinetic characteristics of GPI-Nordhorn are compared with those of the wild type enzyme.

\section{Materials and Methods}

All substrates, coenzymes, and auxiliary enzymes for optical enzyme determinations were purchased from C. F. Boehringer and Sons [11]. Other chemicals (reagent grade) were obtained from E. Merck, AG [12], dialyzing tubes (type 8/32 Visking) from Serva [13], DEAESephadex and Sephadex G-100 and the chromatography columns (K 25/45 and K 16/90 jacketed) from Pharmacia [14.].

The standard assay of GPI activity was performed according to the method of Slein [9] at $25^{\circ}$ in $50 \mathrm{~mm}$ triethanolamine buffer, $\mathrm{pH} 7.5$, containing $1 \mathrm{~mm}$ EDTA. Enzyme activity is expressed in international units. The kinetic studies were performed at $37^{\circ}$ in 50 mм triethanolamine buffer containing $1 \mathrm{mM}$ EDTA, pH 7.2. For the backward reaction the system of Slein was used with G-6-P dehydrogenase as an auxiliary enzyme: $0.3 \mathrm{~mm}$ NADP, F-6-P varied from 2 to 0.02 mM, G-6-P dehydrogenase (purity I) 2 IU, final volume $1.0 \mathrm{ml}$.

For the forward reaction we used the spectrophotometric assay by Kahana et al. [6] based on the linked reactions of phosphofructokinase, pyruvate kinase, and lactate dehydrogenase. The advantage of this system is the recycling of ATP. ATP is maintained at a constant level which is important for the inhibitory effect on phosphofructokinase. We modified the system slightly with regard to the level of ATP: $8 \mathrm{mM} \mathrm{MgCl}_{2}, 75 \mathrm{~mm}$ $\mathrm{KCl}, 1 \mathrm{~mm}$ phosphoenolpyruvate, $0.01 \mathrm{~mm}$ ATP, 0.3 mM NADH, G-6-P varied from 4 to $0.05 \mathrm{~mm}$, lactate dehydrogenase $5 \mathrm{IU}$, pyruvate kinase $1.0 \mathrm{IU}$, and phosphofructokinase $0.8 \mathrm{IU}$, final volume $1.0 \mathrm{ml}$. Because ammonium sulfate is a potent inhibitor of GPI [2], it is necessary to remove it by dialysis $(10 \mathrm{~mm}$ triethanolamine, $1 \mathrm{~mm}$ EDTA, $20 \mathrm{~mm} \mathrm{KCl}, \mathrm{pH} 7.5$, at $4^{\circ}$ for $3 \mathrm{hr}$ ).

Protein content in crude hemolysates was determined as hemoglobin, in enzyme preparations by measuring the absorbance at $280 \mathrm{~nm}$ in $40-\mathrm{mm} \mathrm{cu-}$ vettes in a Beckman DB-G spectrophotometer; a specific extinction of $\mathrm{E}_{1 \mathrm{~cm}}^{1 \%}=10$ was used.

For enzyme preparation [3], 20-30 ml venous blood were collected in acid-citrate-dextrose solution; platelets and leukocytes were removed by cotton wool filtration [5]. Isolated erythrocytes were hemolyzed by digitonin [7]. The hemolysate was dialyzed against $10 \mathrm{~mm}$ Tris buffer containing $1 \mathrm{~mm}$ EDTA, pH 8.0, overnight at $4^{\circ}$, 200-fold volume. DEAE-Sephadex A-50 was prepared for chromatography by careful equilibration to the dialysis buffer and a column (K 25/45 jacketed), which was cooled to $10^{\circ}$, was filled. The dialyzed material was applied to the column by a pump with a constant flow rate of $16 \mathrm{ml} / \mathrm{hr}$. Elution was performed with the same buffer as that used for dialysis and equilibration. Fractions of $6.2 \mathrm{ml}$ were collected and assayed for optical density at $280 \mathrm{~nm}$ and GPI activity.

Isoelectric focusing [10] was performed in an LKB 8101 column, volume $110 \mathrm{ml}$, anode at the top of the column. A pH gradient of 8-10 was used with a concentration of the ampholine of $1 \%$ in a sucrose density gradient. Focusing was carried out at $0.5^{\circ}$ for $120 \mathrm{hr}$. After termination of the experiment fractions of $1.5 \mathrm{ml}$ were collected. $\mathrm{pH}$ was measured at $0^{\circ}$, correcting for $\mathrm{pH}$ deviation of the calibration buffer at this temperature.

The molecular weight was determined by gel chromatography over Sephadex G-100 in a column (K 16/ 90 jacketed) at $10^{\circ}$. In addition to $1 \mathrm{ml}$ hemolysate of the patient with GPI-Nordhorn an appropriate amount of blue dextran and about 10 IU of crystalline aldolase and lactate dehydrogenase were applied to the column. The elution buffer contained $50 \mathrm{~mm}$ triethanolamine, 1 тм EDTA, 50 mм KCl, pH 7.5.

\section{Results}

The results of the purification procedure are summarized in Table 1 . The elution profile of GPI-Nordhorn is demonstrated in Figure 1. Total GPI activity appears as a homogenous peak and is well separated from phosphoglycerate kinase, which is eluted as the next following enzyme. Fractions 12 and 13, containing the main activity $(0.48 \mathrm{IU})$, were combined. The protein concentration was lower than $0.0004 \mathrm{mg} / \mathrm{ml}$. The factor of purification is at least 20,000-fold, specific activity is about $100 \mathrm{IU} / \mathrm{mg}$ protein. No contaminating enzymes were detectable. This part of the preparation was used for the kinetic studies. The yield of the pooled fractions $10-15$ amounted to $45 \%$. 
Table I. Purification of glucose phosphate isomerase (GPI)-Nordhorn from erythrocytes

\begin{tabular}{|c|c|c|c|c|c|c|c|}
\hline & \multirow{2}{*}{ Volume, $\mathrm{ml}$} & \multicolumn{2}{|c|}{ GPI activity } & \multirow{2}{*}{ Protein, $\mathrm{mg} / \mathrm{ml}$} & \multirow{2}{*}{ Sp act, IU/mg protein } & \multirow{2}{*}{ Yield, $\%$} & \multirow[b]{2}{*}{ Purification, -fold } \\
\hline & & $\mathrm{IU} / \mathrm{ml}$ & IU/vol & & & & \\
\hline Hemolysate & 16.0 & 0.1212 & 1.94 & 24.6 & 0.0049 & 100 & 1 \\
\hline Dialysate & 16.6 & 0.1095 & 1.82 & 22.8 & 0.0048 & 94 & 0.98 \\
\hline \multicolumn{8}{|c|}{ DEAE-Sephadex eluates } \\
\hline Fractions 12 and 13 & 12.4 & 0.0385 & 0.48 & $<0.0004$ & $>96$ & 25 & $>20.000$ \\
\hline Fractions $10-15$ & 37.2 & 0.0234 & 0.873 & & & 45 & \\
\hline
\end{tabular}

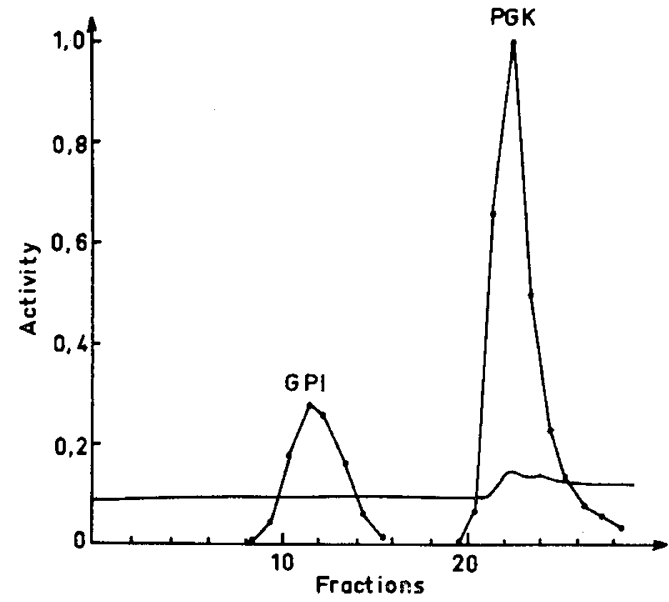

Fig. 1. Purification of glucose phosphate isomerase (GPI)-Nordhorn by Sephadex-DEAE A-50 chromatography; absorbance at $280 \mathrm{~nm}$. $P G K$ : phosphoglycerate kinase.

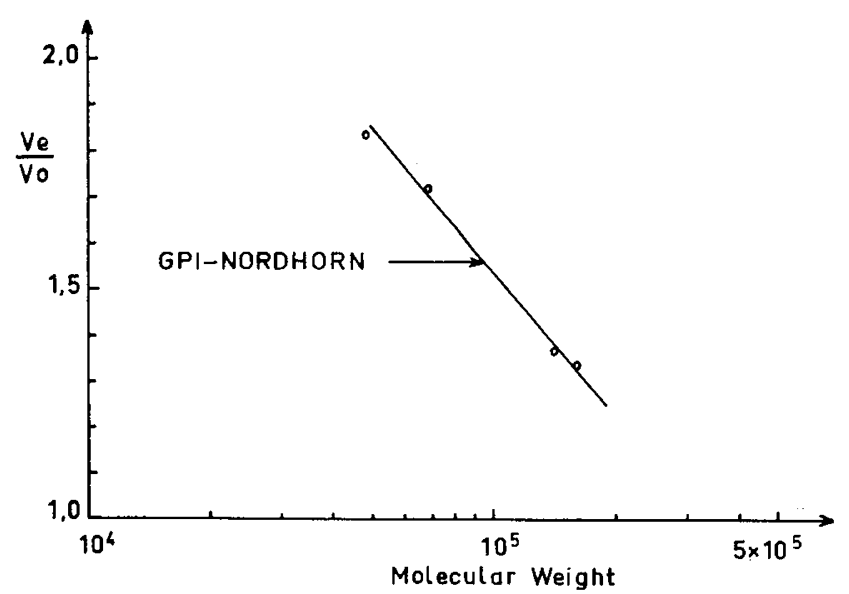

Fig. 2. Determination of molecular weight of glucose phosphate isomerase-Nordhorn (GPI-NORDHORN) by Sephadex G-100 chromatography. Phosphoglycerate kinase ( $\mathrm{mol}$ wt 48,000 ); hemoglobin (mol wt 68,000); lactate dehydrogenase (mol wt 140,000); aldolase (mol wt 160,000).

Figure 2 shows the calibration curve for the determination of the molecular weight. A value of 94,000 was obtained for GPI-Nordhorn. The result of isoelectric

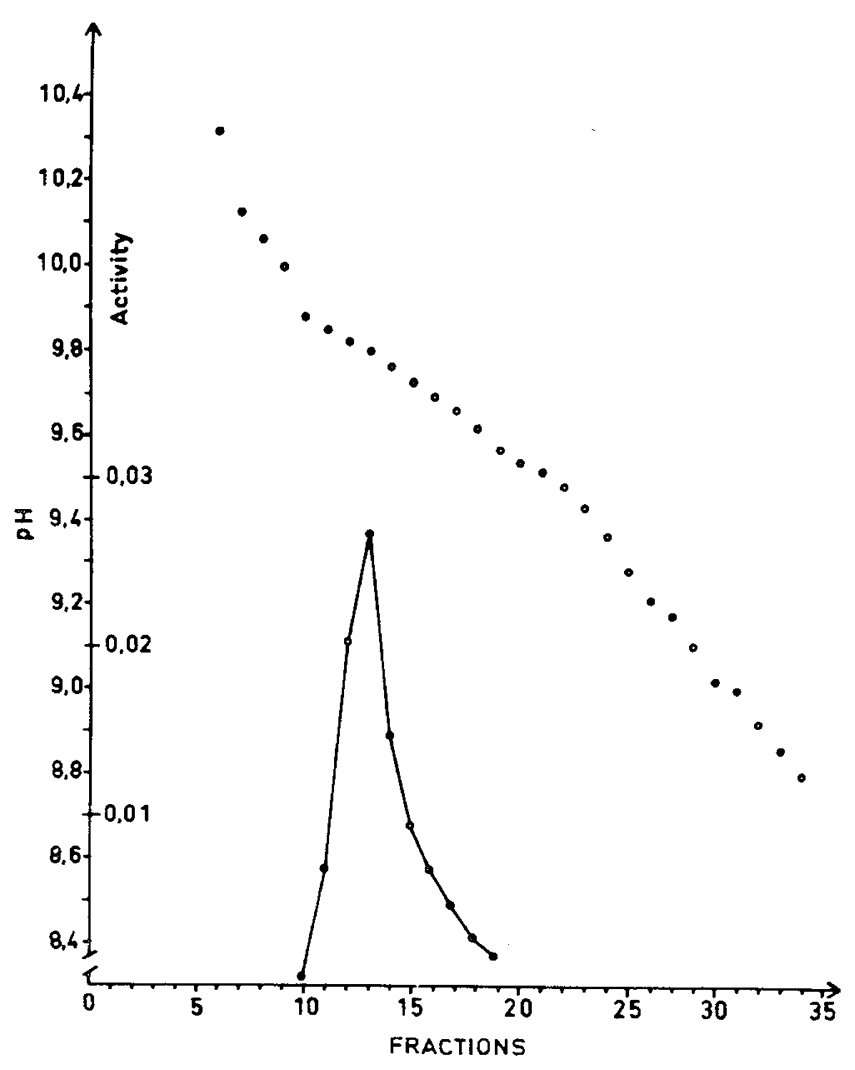

Fig. 3. Determination of the isoelectric point of glucose phosphate isomerase-Nordhorn by isoelectric focusing.

focusing is given in Figure 3. GPI activity is eluted in homogenous peak. The isoelectric point of GPI-Nordhorn is 9.80. Figure 4 demonstrates the effect of $\mathrm{pH}$ on the reaction rate of GPI-Nordhorn in either direction. The optimum for the backward reaction with F-6-P as the substrate is $\mathrm{pH} 8.5$, for the forward reaction with G-6-P as the substrate is pH 8.0. The MichaelisMenten constants $\left(\mathrm{K}_{\mathrm{m}}\right)$ for GPI-Nordhorn, obtained in Lineweaver-Burk plots, were as follows: $\mathrm{K}_{\mathrm{m}}$ (G-6-P) 660 $\mu \mathrm{M}, \mathrm{K}_{\mathrm{m}}$ (F-6-P) $97 \mu \mathrm{M}$. The ratio of maximal velocity $\left(V_{\max }\right)$ of the forward reaction to the backward reaction was 1.16 .

For further characterization, the influence of effec. 


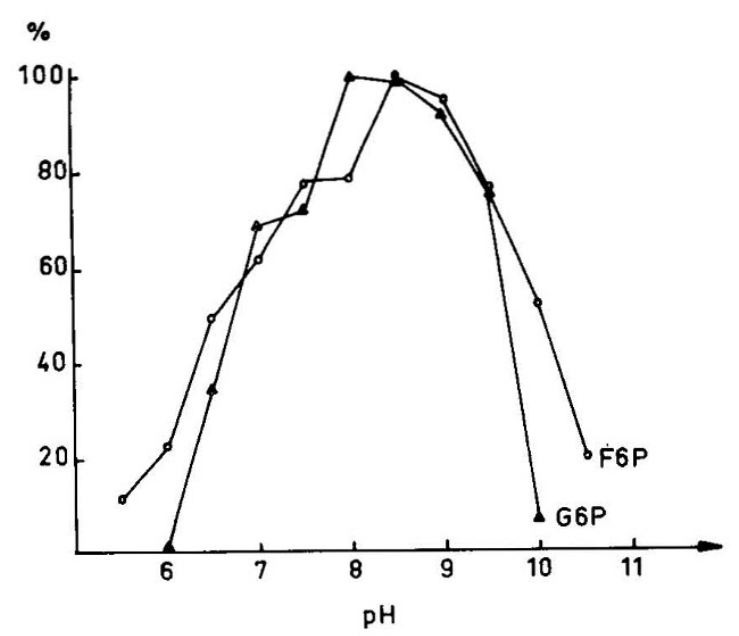

Fig. 4. $\mathrm{pH}$ dependency of forward $(G 6 P)$ and backward $(F 6 P)$ reaction of glucose phosphate isomerase-Nordhorn.

Table II. Physicochemical and kinetic properties of glucose phosphate isomerase (GPI)-Nordhorn in comparison to normal enzyme $^{1}$

\begin{tabular}{|c|c|c|}
\hline Property & Normal GPI [1] & GPI-Nordhorn \\
\hline Mol wt & $88,000-92,000$ & 94,000 \\
\hline Isoelectric point & $9.645 \pm 0.028$ & 9.80 \\
\hline Sp act, IU $/ \mathrm{mg}$ protein ${ }^{2}$ & 820 & 96 \\
\hline $\mathrm{V}_{\max }(\mathrm{G}-6-\mathrm{P}) / \mathrm{V}_{\max }(\mathrm{F}-6-\mathrm{P})$ & $0.96 \pm 0.12$ & 1.16 \\
\hline $\mathrm{K}_{\mathrm{m}}(\mathrm{G}-6-\mathrm{P}), \mu \mathrm{M}$ & $460 \pm 85$ & 660 \\
\hline $\mathrm{K}_{\mathrm{m}}(\mathrm{F}-6-\mathrm{P}), \mu \mathrm{M}$ & $67 \pm 13$ & 97 \\
\hline $\mathrm{pH}$ optimum (G-6-P) & 8.0 & 8.0 \\
\hline $\mathrm{pH}$ optimum (F-6-P) & 8.5 & 8.5 \\
\hline $\mathrm{K}_{\mathrm{i}} 2,3-\mathrm{DPG}(\mathrm{F}-6-\mathrm{P}), \mu \mathrm{M}$ & 940 & 850 \\
\hline $\mathrm{K}_{\mathrm{i}} 6-\mathrm{PG}(\mathrm{G}-6-\mathrm{P}), \mu \mathrm{M}$ & 73 & 43 \\
\hline $\mathrm{K}_{\mathrm{i}} 6-\mathrm{PG}(\mathrm{F}-6-\mathrm{P}), \mu \mathrm{M}$ & 13 & 19 \\
\hline
\end{tabular}

${ }^{1}$ G-6-P: glucose 6-phosphate; F-6-P: fructose 6-phosphate; 2,3-DPG : 2,3-diphosphoglycerate; 6-PG : 6-phosphogluconate. 2 After purification.

tors on GPI was studied. 6-PG and 2,3-DPG inhibit the normal enzyme in a competitive fashion [3]. At a physiologic concentration, 2,3-DPG affects only the backward reaction.

For the backward reaction of GPI-Nordhorn, we found an inhibitor constant $\left(\mathrm{K}_{\mathrm{i}}\right)$ of $850 \mu \mathrm{M}$ for 2,3DPG and of $19 \mu \mathrm{M}$ for 6-PG. For the forward reaction of GPI-Nordhorn, we obtained a $\mathrm{K}_{\mathrm{i}}$ value of $43 \mu \mathrm{M}$ for 6-PG (Table II).

\section{Discussion}

A preparation of GPI-Nordhorn with a specific activity of about $100 \mathrm{IU} / \mathrm{mg}$ protein was obtained. In comparison to the specific activity of the normal enzyme, the value for GPI-Nordhorn is lower. This can be explained by the loss of activity before and cluring the purification process.

The results obtained with hemolysates of GPI-Nordhorn [8] are different from those of the wild type enzyme: abnormal electrophoretic migration and increased thermal lability. The elevated isoelectric point of 9.80 is in accordance to the electrophoretic study which shows a migration of $132 \%$. It can be assumed that in the case of GPI-Nordhorn, the mutation results in a substitution of an amino acid with different charge. This molecular alteration causes an increased lability of the enzyme. It has no effect on the molecular weight of the enzyme protein under the method applied.

The kinetic studies revealed a Michaelis-Menten constant for F-6-P, an inhibitor constant for 2, 3-DPG, and an inhibitor constant for 6-PG for the backward reaction which are normal. The effect of $\mathrm{pH}$ on the reaction rate in both directions is normal. The $\mathrm{K}_{\mathrm{m}}$ value for G-6-P is slightly higher than that for the normal enzyme; the $\mathrm{K}_{\mathrm{i}}$ value for 6-PG of the forward reaction is lower than that for the normal enzyme. The ratio of $V_{\max }$ of the forward to the backward reaction is slightly increased. However, these constants do not differ significantly from normal. It can be assumed that the amino acid substitution in the case of GPI-Nordhorn does not affect a region close to the active site.

\section{Summary}

A new enzyme variant of GPI with nonspherocytic hemolytic anemia is purified and characterized for its biochemical characteristics. The new variant, GPINordhorn, is altered in its isoelectric point, electrophoretic behavior, and thermostability, but shows normal kinetic properties.

\section{References and Notes}

1. ARNol.D, H.: In preparation.

2. Arnol.), H., Blume, K. G., Busch, D., Lenkett, U., Löhr, G. W., AND LÜBs, E.: Klinische und biochemische Untersuchungen zur Glucosephosphatisomerase normaler menschlicher Erythrozyten und bei Glucosephosphatisomerase-Mangel. Klin. Wschr., 48: 1299 (1970).

3. Arnold, H., Hoffmann, A., Engelhardt, R., and Löhr, G. W.: Purification and kinetic properties of glucosephosphate isomerase from human erythrocytes. In: E. Gerlach, K. Moser, E. Deutsch, and W. Wilmanns: Erythrocytes, Thrombocytes, Leukocytes, p. 177 (G. Thicme Verlag, Stuttgart, 1973). 
4. Baughan, M. A., Valentine, W. N., Paglia, D. E., Ways, P. O., Simon, E. R., and Demarsh, Q. B.: Hereditary hemolytic anemia associated with glucosephosphate isomerase (GPI) deficiency: A new enzyme defect of human erythrocytes. Blood, 30: 850 (1967).

5. Busch, D., ANd Pelz, K.: Erythrozytenisolierung aus Blut mit Baumwolle. Klin. Wschr., 46: 983 (1966).

6. Kahana, S. E., Lowry, O. H., Schulz, D. W., Passonneau, J. V., AND CRAwFord, E. J.: The kinetics of phosphoglucoisomerase. J. Biol. Chem. 235: 2178 (1960).

7. LöHR, G. W., AND Waller, H. D.: Glucose-6-phosphat-Dehydrogenase (Zwischenferment). In: H. U. Bergmeyer: Methoden der enzymatischen Analyse, p. 741 (Chemie-Verlag, Weinheim, Bergstrasse, 1962).

8. Schröter, W., Koch, H. H., Wonneberger, B., Kalinowsky, W., Arnold, H., Blume, K. G., ANd HÜter, H.: Glucose phosphate isomerase deficiency with congenital nonspherocytic hemolytic anemia: A new variant (type $\mathrm{N}$ ordhorn). I. Clinical and genetical studies. Pediat. Res., in press.

9. SLeIN, M. W.: Phosphohexoisomerase from muscle. Methods Enzymol., 1: 299 (1955).

10. Vesterberg, O., ANd Svensson, H.: Isoelectric fractionation, analysis and characterization of ampholytes in natural $\mathrm{pH}$ gradients. Acta Chem. Scand., 20: 820 (1966).

11. Mannheim, Germany.

12. Darmstadt, Germany.

13. Heidelberg, Germany.

14. Uppsala, Sweden.

15. The authors gratefully acknowledge the valuable assistance of Mrs. K. Hasslinger and Miss C. Stach.

16. Requests for reprints should be addressed to: H. ARNOLD, M.D., D-78 Freiburg, Department of Internal Medicine, University of Freiburg, Freiburg, Germany.

17. Accepted for publication September 12, 1973. 